\title{
Pemberian taburia (sprinkle) berpengaruh terhadap lama dan frekuensi diare akut anak
}

\author{
Sprinkle (taburia) supplementation influences the duration and frequency of acute diarrhea in children
}

Sopiyandi ${ }^{1}$, Muhammad Juffrie ${ }^{2}$, Susetyowati ${ }^{3}$

\begin{abstract}
Background: Major causes of mortality in children are diarrhea and pneumonia (25.2\% and 15.5\%). "Five steps of diarrhea management" is an integrated approach in the management of diarrhea comprising the supplementation of oral rehydration, zinc within 10 days subsequently, breastfeeding and food, selective antibiotics and advice for the mother/family. Zinc supplementation combined with vitamin A and micronutrient on children with the diarrhea had been researchead that result can minimize morbidity, duration and frequency of diarrhea, and the incidence of recurrent diarrhea.

Objective: To find out the effect of taburia supplementation (sprinkle) on duration and frequency of diarrhea.

Method: The study was randomized controlled trial (RCT) with parallel design. Subject consisted of two groups, the first got therapy of taburia (sprinkle) 1 sachet/day and the second was the control group. Each group got standard diarrhea medication at the health center. Samples consisted of 30 children of 1-5 years old per group and they were obtained by using simple randomization technique. Statistical analysis was performed by using Chi-Square and t-test.

Result: Duration of diarrhea of the experiment group was $33.25 \pm 18.08$ hours (95\% Cl: $26.49-40.00$ ) and the control group was $43.7 \pm 19.25$ hours (95\% Cl: $36,50-50,89)$. Frequency of diarrhea of the experiment group was $4.93 \pm 3.41$ times/day (95\% Cl: 3,41-3,65) and the control group was $6.33 \pm 3.20$ times/day (95\% Cl: 5.13-7.53). The result of statistic test showed that there was effect of taburia supplementation to duration and frequency of diarrhea $(p<0.05)$.

Conclusion: Supplementation of taburia (sprinkle) in the standard therapy of diarrhea shortened the duration and minimized the frequency of diarrhea.
\end{abstract}

KEY WORDS: acute diarrhea, duration of diarrhea, frequency of diarrhea

\begin{abstract}
ABSTRAK
Latar belakang: Penyebab kematian balita terbanyak adalah diare dan pnemonia (25,2\% dan 15,5\%). Lima langkah tuntaskan diare yaitu pemberian oralit, pemberian tablet zink selama 10 hari berturut-turut, teruskan pemberian ASI dan makan, pemberian antibiotik secara selektif, dan pemberian nasihat pada ibu/keluarga. Penelitian pemberian zink dengan kombinasi vitamin A dan mikronutrien pada anak diare menunjukkan terjadinya penurunan morbiditas, durasi, frekuensi, dan diare berulang.

Tujuan: Mengetahui pengaruh suplementasi taburia (sprinkle) terhadap lama dan frekuensi diare akut pada anak.

Metode: Penelitian RCT ini dilakukan dengan desain paralel. Subjek dibedakan menjadi dua kelompok yaitu kelompok pertama mendapatkan terapi tambahan taburia (sprinkle) 1 sachet/hari dan kelompok kedua sebagai kontrol. Masingmasing kelompok mendapatkan terapi baku pengobatan diare di puskesmas. Subjek adalah anak usia 1-5 tahun yang menderita diare akut dan dipilih berdasarkan random allocation menggunakan teknik simple randomization dengan besar sampel masing-masing kelompok sebesar 30 anak. Analisis statistik dilakukan dengan menggunakan uji ChiSquare dan t-test.

Hasil: Lama diare pada kelompok perlakuan sebesar 33, $25 \pm 18$,08 jam (95\% Cl: 26, 49-40,00) dan kontrol 43,7 $\pm 19,25$ jam (95\% Cl: 36,50 - 50,89). Frekuensi diare pada kelompok perlakuan sebesar 4,93 \pm 3,41 kali/hari (95\% Cl: 3,413,65) sedangkan kontrol 6,33 $\pm 3,20$ kali/hari (95\% Cl: 5.13-7.53). Hasil uji statistik menunjukkan terdapat pengaruh penambahan taburia (sprinkle) terhadap lama dan frekuensi diare $(p<0,05)$.

Simpulan: Penambahan taburia (sprinkle) dalam terapi baku diare memperpendek lama diare dan memperkecil frekuensi diare.
\end{abstract}

KATA KUNCI: diare akut, lama diare, frekuensi diare

\footnotetext{
${ }^{1}$ Korespondensi: Jurusan Gizi Politeknik Kesehatan Kementerian Kesehatan Pontianak, Jl. 28 Oktober Siantan Hulu Pontianak, Kalimantan Barat, Telp. 081257686869, e-mail: yandiadilphoto@yahoo.co.id

2 Bagian Ilmu Kesehatan Anak Rumah Sakit Umum Pusat Dr. Sardjito/Fakultas Kedokteran Universitas Gadjah Mada, JI. Kesehatan No 1, Yogyakarta, e-mail: juffrie@indosat.net.id

${ }_{3}^{3}$ Program Studi Gizi Kesehatan, Fakultas Kedokteran Universitas Gadjah Mada, JI. Farmako, Sekip Utara Yogyakarta 55281, e-mail: susetyowati2000@ yahoo.com
} 


\section{PENDAHULUAN}

Penyebab pertama kematian pada bayi dan anak balita di Indonesia adalah penyakit diare dengan prevalensi $5,4 \%$. Menurut data Riset Kesehatan Dasar (Riskesdas) tahun 2007, prevalensi penyakit diare balita sebesar $25,2 \%$ dan pnemonia $15,5 \%$ yang penyebarannya hampir terjadi di seluruh wilayah Indonesia, termasuk di Provinsi Kalimantan Barat (1).

Lima langkah tuntaskan diare (Lintas Diare) merupakan salah satu manajemen terpadu dalam penanganan diare saat ini. Lima langkah tersebut meliputi pemberian oralit, pemberian tablet zink selama 10 hari berturut-turut, teruskan pemberian air susu ibu (ASI) dan makan, pemberian antibiotik secara selektif, dan pemberian nasihat pada ibu atau keluarga (2). Pemberian zink (Zn) dengan kombinasi vitamin A dan mikronutrien menunjukkan terjadinya penurunan angka morbiditas pada anak diare yang stunted di Afrika Selatan. Dosis pemberian zink dan vitamin A pada penelitian tersebut masing-masing sebesar $10 \mathrm{mg}$ dan $1250 \mathrm{IU}$, serta mikronutrien yang terdiri dari B1, B2, B6, B12, C, D, E, K, tembaga (Cu), niasin (B3), folat (B9), yodium (I), dan besi (Fe) (3). Selain manfaat dari zink, vitamin A juga diyakini dapat meningkatkan sistem imunitas anak dan memperbaiki mukosa usus (4). Penelitian di Pakistan menyatakan pentingnya asupan dan keseimbangan mikronutrien seperti vitamin dan mineral pada pencegahan dan terapi diare sehingga dapat mengurangi prevalensi diare yang berdampak pada penurunan angka kematian diare pada anak (5).

Penelitian ini bertujuan untuk mengetahui pengaruh suplementasi taburia (sprinkle) yang berisi mikronutrien berupa vitamin A (417 mcg), B1 (0,5 mg), B2 (0,5 mg), B3 (5,0 mg), B6 (0,5 mg), B12 (1,0 mcg), C (30,0 mg), D3 $(5,0 \mathrm{mcg}), \mathrm{E}(6,0 \mathrm{mg}), \mathrm{K}(20,0 \mathrm{mcg})$, folat $(150,0 \mathrm{mcg})$, asam pantotenat $(3,0 \mathrm{mg})$, Fe (10,0 mg), Zn (5,0 mg), I $(50,0 \mathrm{mcg})$, dan selenium $(20,0 \mathrm{mcg})$ terhadap lama dan frekuensi diare akut anak. Penelitian ini ingin membuktikan apakah penambahan taburia (sprinkle) pada anak diare akut akan memperpendek atau mengurangi lama dan frekuensi diare dibandingkan anak penderita diare akut yang hanya mendapatkan terapi baku saja berupa Lintas Diare.

\section{BAHAN DAN METODE}

Penelitian ini merupakan penelitian randomized controlled trial (RCT) menggunakan desain paralel dengan randomisasi (6) yang dilaksanakan di puskesmas wilayah kerja Unit Pelaksana Teknis Daerah (UPTD) Pontianak Timur, Kota Pontianak pada bulan Januari - Maret 2012. Populasi target pada penelitian ini adalah anak umur di bawah 5 tahun yang menderita diare akut sedangkan populasi terjangkau adalah bagian dari anak dengan diare akut yang dibawa ke puskesmas selama penelitian berlangsung. Subjek penelitian adalah anak usia 1-5 tahun dan menderita diare akut yang diambil dari populasi target serta memenuhi kriteria inklusi dan eksklusi penelitian. Pemilihan subjek secara random allocation menggunakan teknik random sederhana (simple randomization) melalui tabel random.

Kriteria inklusi yaitu anak diare akut usia 1-5 tahun, orang tua atau wali menyetujui anaknya dilibatkan dalam penelitian, bersedia mengikuti prosedur penelitian, dan menandatangani formulir persetujuan (informed consent). Kriteria eksklusi yaitu mempunyai kelainan kongenital pada saluran cerna (megakolon), menderita penyakit penyerta yang berat yaitu penurunan kesadaran (somnolen hingga koma), gangguan hemodinamik (asidosis), gangguan kardiovaskular, gangguan respirasi berat, diare yang disebabkan karena imunodefisiensi (HIVIAIDS), alergi, malabsorpsi maupun gizi buruk (secara klinis maupun antropometri) yang ditetapkan oleh dokter di puskesmas. Subjek penelitian dinyatakan drop out jika orang tua subjek pindah alamat sehingga tidak dapat dipantau, orang tua memutuskan untuk tidak melanjutkan penelitian, atau anak diberikan pengobatan lain selain terapi baku yang diberikan di puskesmas selama penelitian berjalan.

Besar sampel ditentukan menggunakan rumus uji hipotesis satu arah terhadap beda rerata dengan kemaknaan 95\%, kekuatan 90\% (7), serta outcome adalah lama rawat diare pada perlakuan selama 1,32 hari dan pada kontrol 2,88 hari dengan nilai standar deviasi 2,03 hari (8) sehingga besar sampel minimal pada masing-masing kelompok sebesar 30 subjek. Kelompok kontrol hanya mendapatkan terapi baku (Lintas Diare) sedangkan kelompok perlakuan selain mendapatkan pengobatan baku, juga diberikan tambahan taburia (sprinkle) dengan dosis 1 sachet setiap hari sampai sembuh (maksimal 7 hari). Cara penggunaan sprinkle yaitu ditaburkan pada makanan yang siap dimakan oleh anak saat makan pagi. Apabila anak sudah sembuh pada hari ketiga setelah pengobatan, maka taburia (sprinkle) tidak dilanjutkan pada hari berikutnya. Berbeda dengan zink pada terapi baku yang tetap diberikan hingga 10 hari meskipun anak sudah sembuh. Cara alokasi perlakuan dilakukan menggunakan tabel random.

Variabel independen adalah suplementasi taburia (sprinkle), variabel dependen adalah lama dan frekuensi diare, dan variabel luar adalah status gizi. Taburia (sprinkle) adalah vitamin dan mineral dalam kemasan sachet $1 \mathrm{~g}$ yang diproduksi oleh Departemen Kesehatan melalui program Nutrition Improvement Through Community Empowerment (NICE). Dosis pemberian 1 sachet per hari mengandung 12 vitamin dan 4 mineral yang terdiri dari vitamin $A$ (417 $\mathrm{mcg}), \mathrm{B} 1$ (0,5 mg), B2 (0,5 mg), B3 (5,0 mg), B6 (0,5 mg), $B 12(1,0 \mathrm{mcg}), C(30,0 \mathrm{mg}), \mathrm{D} 3(5,0 \mathrm{mcg}), \mathrm{E}(6,0 \mathrm{mg}), \mathrm{K}$ $(20,0 \mathrm{mcg})$, folat $(150,0 \mathrm{mcg})$, asam pantotenat $(3,0 \mathrm{mg})$, Fe $(10,0 \mathrm{mg}), \mathrm{Zn}(5,0 \mathrm{mg}), \mathrm{I}(50,0 \mathrm{mcg})$, dan selenium 


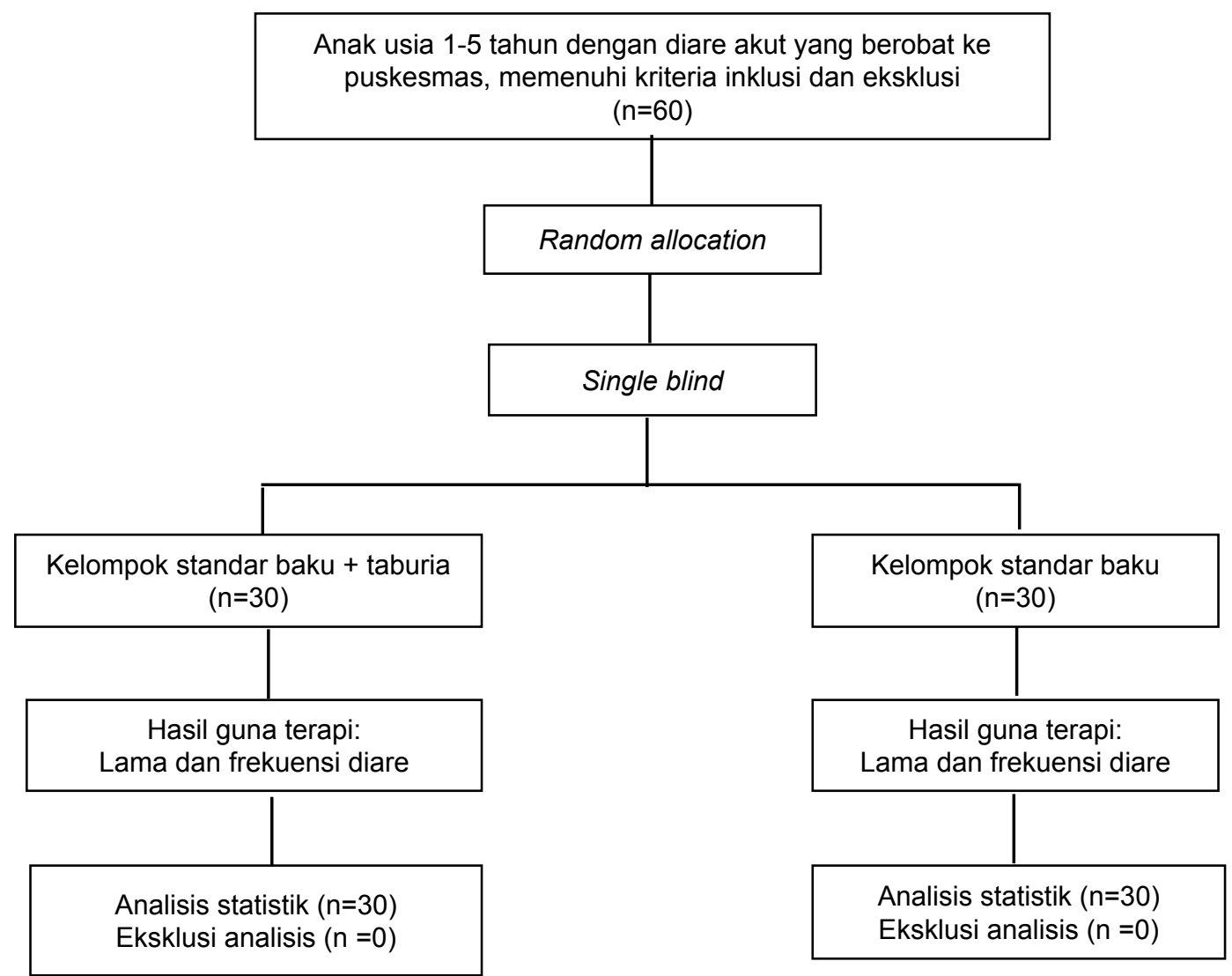

Gambar 1. Alur penelitian

(20,0 mcg) (9). Anjuran kecukupan gizi harian zink untuk anak sehat dengan usia 1-3 dan 4-6 tahun adalah 8,2 mg dan $9,7 \mathrm{mg}$ (10). Pada penelitian ini, jumlah zink yang diberikan pada anak sebesar $25 \mathrm{mg}$ yaitu $5 \mathrm{mg}$ berasal dari taburia (sprinkle) dan $20 \mathrm{mg}$ dari terapi lintas diare, ini relatif masih aman mengingat jumlah tersebut berkisar 3 kali dari angka kecukupan gizi (AKG). Kelebihan zink biasanya disebabkan oleh suplementasi dan transfusi dengan asupan melebihi $1 \mathrm{~g} / \mathrm{hari}$ atau melebihi $60 \mathrm{kali}$ dari AKG sehingga akan menyebabkan mual, muntah, dan kelelahan yang berlebihan.

Diare akut adalah buang air besar lebih dari 3 kali dalam 24 jam dengan konsistensi cair dan berlangsung kurang dari 7 hari (11). Lama diare adalah jumlah jam sakit diare semenjak pasien menjalani pengobatan di puskesmas hingga saat pertama konsistensi tinja menjadi lembek dan atau frekuensi kurang dari 3 kali dalam sehari yang diikuti keadaan menetap menggunakan alat ukur kalender even/formulir pencatatan. Setelah periode diare, jika anak mengalami diare kembali maka dianggap episode baru diare. Frekuensi diare adalah jumlah berapa kali buang air besar (BAB) dengan konsistensi cair, semenjak pengobatan di puskesmas hingga saat pertama konsistensi tinja menjadi lembek dan atau frekuensi BAB kurang dari 3 kali dalam sehari yang diikuti keadaan menetap menggunakan alat ukur kalender even/formulir pencatatan.
Pengukuran status gizi berupa panjang badan atau tinggi badan menggunakan alat ukur length-board atau microtoise kemudian dibandingkan dengan umur (TB/U) berdasarkan nilai z-skor baku antropometri balita WHO 2005 dengan kategori pendek (z-skor <-2) dan normal (z-skor $\geq-2$ ) (1). Pengukuran dilakukan oleh enumerator yang berpendidikan S1 atau DIII Gizi pada awal pasien datang ke puskesmas untuk menjalani pengobatan.

Keragaman variasi antara kelompok kasus dan kontrol diketahui dengan melakukan Chi-Square test sedangkan $t$-test dilakukan untuk mengetahui pengaruh pemberian taburia (sprinkle) terhadap lama dan frekuensi diare dengan menggunakan software stata 11. Penelitian ini telah mendapatkan persetujuan dari Komisi Etik Penelitian Kedokteran dan Kesehatan Fakultas Kedokteran Universitas Gadjah Mada Yogyakarta No Ref: KE/FK/370/ EC.

\section{HASIL}

\section{Karakteristik subjek penelitian}

Tiga puluh subjek penelitian mendapatkan terapi baku ditambah dengan taburia (sprinkle) (kelompok perlakuan) dan 30 lainnya hanya mendapatkan terapi baku saja (kelompok kontrol). Semua subjek dapat mengikuti penelitian hingga selesai dan tidak ada yang drop out 
Tabel 1. Karakteristik subjek penelitian

\begin{tabular}{lcc}
\hline \multicolumn{1}{c}{ Variabel } & $\begin{array}{c}\text { Perlakuan } \\
(\mathbf{n = 3 0 )}\end{array}$ & $\begin{array}{c}\text { Kontrol } \\
(\mathbf{n = 3 0})\end{array}$ \\
\hline $\begin{array}{l}\text { Mean umur (bulan) } \\
\text { Status gizi (n,\%) }\end{array}$ & $28,16 \pm 12,25$ & $23,53 \pm 10,01$ \\
$\quad$ Pendek & $11(37)$ & $12(40)$ \\
$\quad$ Normal & $19(63)$ & $18(60)$ \\
$\begin{array}{l}\text { Jenis kelamin (n,\%) } \\
\text { Laki-laki }\end{array}$ & $17(57)$ & $16(53)$ \\
$\quad$ Perempuan & $13(43)$ & $14(47)$ \\
\hline
\end{tabular}

Tabel 2. Pengaruh taburia (sprinkle) terhadap lama dan frekuensi diare

\begin{tabular}{ccccc}
\hline Kelompok & Rerata (SD) & $\begin{array}{c}\text { Mean } \\
\text { difference }\end{array}$ & $\mathbf{p}$ & $\mathbf{9 5 \%} \mathbf{~ C l}$ \\
\hline Lama diare (jam) & $33,25 \pm 18,08$ & 10,45 & 0,017 & $26,49-40,00$ \\
$\quad \begin{array}{c}\text { Perlakuan } \\
\text { Kontrol }\end{array}$ & $43,7 \pm 19,25$ & & & $36,50-50,89$ \\
$\begin{array}{c}\text { Frekuensi (kali) } \\
\quad \text { Perlakuan }\end{array}$ & $4,93 \pm 3,41$ & 1,4 & 0,050 & $3,41-3,65$ \\
Kontrol & $6,33 \pm 3,20$ & & & $5.13-7.53$ \\
\hline
\end{tabular}

(Gambar 1). Rerata umur kelompok perlakuan adalah $28,16 \pm 12,25$ bulan dan sebagian besar memiliki status gizi normal. Karakteristik subjek pada kelompok perlakuan maupun kontrol tidak menunjukkan perbedaan bermakna (Tabel 1).

Rata-rata konsumsi taburia (sprinkle) pada kelompok perlakuan sebanyak 3 sachet selama sakit diare yaitu 1 sachet per hari. Kelompok perlakuan dan kontrol mendapatkan terapi baku pengobatan diare, salah satunya adalah pemberian tablet zink $20 \mathrm{mg}$ yang dikonsumsi setiap hari hingga hari ke-10 dengan kepatuhan pada kedua kelompok baik, yaitu zink tersebut selalu dikonsumsi selama terapi.

\section{Pengaruh taburia (sprinkle) terhadap lama dan frekuensi diare}

Hasil penelitian secara umum menunjukkan perbedaan rerata lama diare pada kelompok perlakuan jika dibandingkan dengan kontrol. Kelompok perlakuan mempunyai lama diare yang lebih singkat yaitu $33,25 \pm$ 18,08 jam jika dibandingkan dengan kelompok kontrol sebanyak 43,7 $\pm 19,25 \mathrm{jam}$. Demikian juga pada frekuensi diare yang menunjukkan bahwa kelompok perlakuan lebih sedikit yaitu 4,93 $\pm 3,41$ kali dibandingkan dengan 6,33 \pm 3,20 kali pada kelompok kontrol (Tabel 2).

\section{BAHASAN}

Sebanyak 60 anak diare akut dibagi menjadi dua kelompok yaitu kelompok perlakuan yang mendapatkan penambahan taburia (sprinkle) dalam terapi baku anak diare dan kelompok kontrol yang mendapatkan terapi baku saja. Selama penelitian, semua subjek dapat mengikuti hingga akhir dan tidak ada yang drop out. Rata-rata taburia yang dikonsumsi pada kelompok perlakuan sebanyak 3 sachet per hari secara berturut-turut. Hasil penelitian menunjukkan lama dan frekuensi diare pada kelompok perlakuan adalah $33,25 \pm 18,08$ jam $(95 \% \mathrm{Cl}$ : 26,49 $40,00)$ dan $4,93 \pm 3,41$ kali $(95 \%$ Cl: $3,41-3,65)$ sedangkan kelompok kontrol memiliki lama dan frekuensi diare sebanyak 43,7 $\pm 19,25$ jam (95\% Cl: $36,50-50,89)$ dan $6,33 \pm 3,20$ kali $(95 \% \mathrm{Cl}: 5,13-7,53)$. Jika dibandingkan antara kedua kelompok tersebut, terlihat ada perbedaan sebesar 10,45 jam lebih pendek lama diare serta 1,4 kali lebih sedikit frekuensi diare pada kelompok perlakuan.

Secara klinis, hal ini dapat mencegah seorang anak mengalami dehidrasi yang lebih lama dan berat, mengingat sebagian besar kejadian diare akut mengakibatkan dehidrasi. Selain itu, waktu penyembuhan yang cepat ini juga memungkinkan anak diare akut berisiko lebih kecil untuk berlanjut menjadi diare kronis maupun mengalami penurunan status gizi. Hasil analisis menunjukkan bahwa perlakuan pada kedua kelompok penelitian berpengaruh bermakna pada lama dan frekuensi diare $(p=0,017$ dan $p=0,05)$. Berdasarkan karakteristik subjek pada kedua kelompok yang tidak menunjukkan perbedaan bermakna dan variabel luar yaitu status gizi yang tidak mempunyai pengaruh terhadap lama dan frekuensi diare, maka kemungkinan penyembuhan dipengaruhi oleh adanya perlakuan penambahan taburia (sprinkle) pada terapi baku anak diare.

Namun, kelemahan penelitian ini adalah tidak dilakukan pemeriksaan kultur feses sehingga tidak diketahui penyebab pasti diare tersebut. Upaya mengetahui penyebab dilakukan dengan cara pengamatan terhadap fisik feses. Selain itu, tidak dilakukan pengukuran terhadap konsumsi makanan dan jumlah subjek yang kecil sehingga memungkinkan kesulitan untuk menggeneralisasikan ke suatu populasi. Sebaliknya, kelebihan penelitian ini adalah tingkat kepatuhan dan daya terima subjek terhadap terapi pada kedua kelompok yang sangat baik dan tidak ada subjek yang drop out.

Penambahan taburia (sprinkle) dalam penelitian ini lebih menitikberatkan pada komposisinya yang dapat mendukung proses penyembuhan. Zink yang sampai saat ini telah terbukti luas memiliki manfaat dalam kesehatan, khususnya pada periode diare akut, akan mengurangi lama dan keparahannya bahkan mengurangi berulangnya periode diare. Taburia (sprinkle) hanya memiliki kadar zink sebesar $5 \mathrm{mg}$, tetapi nilai tersebut merupakan komponen penting untuk memenuhi asupan harian zink anak balita. Hingga saat ini, sebagian besar anak balita mengalami kekurangan zat gizi makro maupun mikro seperti halnya zink. Banyak anak mengalami defisiensi zink karena mengonsumsi makanan dengan kandungan fitat dan serat yang tinggi serta sedikit sekali mengonsumsi daging sehingga mengurangi bioavailabilitas zink (12). 
Anjuran kecukupan gizi harian zink untuk anak sehat dengan usia 1-3 dan 4-6 tahun adalah 8,2 mg dan 9,7 mg sehingga dengan diberikannya taburia (sprinkle) dapat memberikan sumbangan asupan sebesar $55 \%$ dari kecukupan zink balita, adapun sisanya dapat terpenuhi dari makanan yang dikonsumsi anak balita (10). Jumlah keseluruhan zink yang diberikan pada anak sebesar 25 mg yaitu $5 \mathrm{mg}$ berasal dari taburia (sprinkle) dan $20 \mathrm{mg}$ dari terapi lintas diare. Hal ini relatif masih aman mengingat jumlah tersebut berkisar 3 kali dari AKG. Selain itu, hal ini juga diperkuat dengan tidak adanya laporan dari orang tua subjek mengenai efek samping yang ditimbulkan seperti mual atau muntah setelah mengonsumsi taburia (sprinkle). Pada orang dewasa, gejala kelebihan zink terlihat jika seseorang mengonsumsi zink dengan dosis melebihi $150 \mathrm{mg} / \mathrm{hari}$ atau lebih dari 10 kali AKG dalam jangka waktu yang lama. Di samping itu, keracunan akibat overdosis lewat suplementasi dan transfusi bisa terjadi jika asupan melebihi $1 \mathrm{~g} / \mathrm{hari}$ atau melebihi 60 kali dari AKG sehingga akan menyebabkan mual, muntah, dan kelelahan yang berlebihan $(13,14)$.

Peranan zink dalam pengobatan diare memiliki titik tangkap dalam mempengaruhi fungsi imunitas terhadap infeksi, fungsi dan struktur intestinal serta berperan dalam proses pemulihan epitel usus selama periode diare $(12,15)$. Lebih lanjut, terdapat beberapa peranan zink dalam hal patogenesis diare yaitu pertama adalah cara kerjanya dengan mempengaruhi beberapa enzim untuk memperbaiki pencernaan, kedua adalah memicu regenerasi sel epitel usus yang rusak akibat diare. Zink membantu perbaikan sel karena dibutuhkan untuk pembentukan inti sel. Ketiga, membantu meningkatkan sistem kekebalan selular, kombinasi fungsi inilah yang membuat zink sangat baik untuk pengobatan diare. Zink sendiri diindikasikan untuk semua jenis diare, baik diare akut, kronis, maupun persisten (16).

Pengobatan dengan zink memiliki efek baik yang bermakna dalam alur klinis diare akut, diperkirakan dapat mengurangi durasi diare hingga $25 \%(13,17)$. Proporsi episode diare lebih dari tujuh hari juga dapat dikurangi hingga mencapai $25 \%$, dengan demikian secara bermakna mengurangi proporsi episode diare yang menjadi persisten. Selain manfaat di atas, manfaat lainnya yaitu terhadap penurunan volume tinja yang dalam beberapa studi memperkirakan berkurangnya tinja sebanyak $30 \%$. Berdasarkan hasil tersebut, dapat disimpulkan bahwa pengobatan dengan zink memiliki dampak klinis yang bermakna terhadap berkurangnya jangka waktu diare akut, tingkat keparahan, dan durasi diare (13).

Komponen penting lainnya dalam taburia (sprinkle) yang dapat mempercepat penyembuhan adalah adanya vitamin A. Vitamin A memiliki peranan yang penting dalam hal perbaikan mukosa usus, selain berperan dalam peningkatan sistem imunitas. Taburia (sprinkle) mengandung vitamin A sebanyak $417 \mathrm{mcg}$ dan ini cukup untuk memenuhi kebutuhan harian anak (18). Penelitian ini juga mendukung hasil penelitian di Brazil dan India yang menyatakan bahwa titik tangkap vitamin A dalam terapi diare akut adalah dalam meningkatkan sistem imunitas anak dan memperbaiki mukosa usus. Peran vitamin A tersebut adalah menjaga integritas lapisan sel epitel saluran pencernaan dan status imunologi $(4,19)$.

Hasil penelitian ini menunjukkan lama dan frekuensi diare yang lebih pendek, hal ini juga memperkuat hasil penelitian di Amerika Serikat yang menyatakan bahwa suplementasi vitamin A pada penanganan penyakit diare akut dapat mengurangi total durasi diare dengan mengurangi kerusakan mukosa usus dan meningkatkan perbaikan sel-sel usus terutama setelah kejadian diare. Lebih lanjut, menemukan bahwa terjadi penurunan keparahan diare pada subjek yang telah mendapatkan suplementasi vitamin A (20).

Beberapa peneliti lain juga membuktikan bahwa salah satu organ utama efek imunologik dari vitamin A adalah usus dan vitamin A merupakan salah satu mikronutrien esensial sistem imun tubuh. Secara langsung, vitamin A dapat memulihkan dan mempertahankan integritas epitel yang rusak sehingga menekan translokasi mikroorganisme dan infeksi lebih lanjut (4). Penelitian ini juga telah memperkuat penelitian sebelumnya mengenai pemberian vitamin A secara tunggal pada anak diare akut dengan dosis 100.000 IU (usia 6-11 bulan) dan 200.000 IU (12-59 bulan), dengan hasil bahwa pemberian vitamin A efektif mengurangi keparahan diare akut pada anak sehingga bermanfaat dalam pengobatan diare akut (21). Selain itu, hasil penelitian di Kota Palu juga menemukan hubungan bermakna antara pemberian vitamin $A$ dengan insiden atau kejadian diare (22).

Penelitian yang menggabungkan zink dengan multivitamin dan multimineral pada pengobatan diare telah dilakukan di Afrika Selatan pada anak stunted yang mengalami diare, yaitu zink yang diberikan $10 \mathrm{mg}$; vitamin A $1250 \mathrm{IU} ; 0,5 \mathrm{mg}$ vitamin B1, B2, dan B6; 0,9 mg vitamin B12; 35 mg vitamin C; 5 ug vitamin D; 6 mg vitamin E; 10 $\mathrm{mg}$ vitamin $\mathrm{K} ; 0,6 \mathrm{mg}$ tembaga; 150 ug folat; $50 \mathrm{mg}$ yodium; $10 \mathrm{mg}$ besi sebagai fumerate besi, dan $6 \mathrm{mg}$ niasin. Hasilnya adalah dapat menurunkan angka morbiditas pada anak diare yang stunted (3). Penelitian lainnya di Pakistan pada anak 6-12 bulan dengan risiko diare, mengungkapkan pentingnya asupan dan keseimbangan mikronutrien seperti vitamin dan mineral pada pencegahan dan terapi diare pada anak. Penelitian tersebut memberikan mikronutrien berupa sprinkle (termasuk zink) serta vitamin A (300 mg) yang dikombinasikan dengan zink, hasilnya adalah pemberian harian gizi mikro (termasuk zink) dapat mengurangi prevalensi diare, dengan demikian akan mengurangi angka kematian diare pada anak-anak (5).

Studi mengenai pemberian mikronutrien (Vitalita) berupa multivitamin dan multimineral pada anak usia 
12-24 bulan penderita gizi kurang, dapat mengurangi risiko diare berulang, menurunkan insiden diare, proporsi diare, dan jumlah hari diare (23). Kedua penelitian yang dilakukan di tempat berbeda yaitu di Jakarta dan Brazil juga membuktikan bahwa terjadi penurunan insiden diare dan ISPA sebelum dan sesudah perlakuan dengan pemberian fortifikasi multi-mikronutrien pada balita $(24,25)$.

Hasil penelitian ini mendukung hasil penelitian sebelumnya di Afrika Selatan (3) dan Pakistan (5) yang menunjukkan hasil bermakna dengan komposisi suplementasi yang hampir sama. Hal ini membuktikan pentingnya zat gizi yang memadai dan lengkap untuk penyembuhan suatu penyakit seperti halnya diare. Taburia (sprinkle) yang merupakan multivitamin dan multimineral pada penelitian ini dapat diberikan pada balita yang mengalami diare akut, baik yang disebabkan oleh virus maupun bakteri. Hal ini diperkuat dengan kondisi fisik feses sebagai indikasi penyebab dari diare akut tersebut, meskipun tidak dilakukan pemeriksaan kultur feses. Sebagian besar kondisi fisik feses tidak berlendir dan hanya sebagian kecil kondisi fisik feses yang ditemukan ada darahnya (3,3\% untuk perlakuan dan $6,67 \%$ untuk kontrol).

Hasil penting lainnya yang ditemukan dalam penelitian ini adalah kepatuhan dari subjek pada kelompok perlakuan dalam mengonsumsi taburia (sprinkle). Taburia (sprinkle) yang dikonsumsi beserta makanan sehari-hari, tidak mengubah kebiasan makan anak. Anak-anak dapat makan seperti biasanya tanpa merasa terganggu meskipun cara pemberian taburia (sprinkle) ditaburkan pada makanan. Pada awal penelitian, terdapat 2 anak yang menolak makanannya diberi taburia (sprinkle). Namun, ketika taburia (sprinkle) tetap ditaburkan pada makanan tanpa sepengetahuannya, ternyata anak mau mengonsumsi makanannya kembali. Hal ini mengindikasikan bahwa taburia (sprinkle) tidak berasa, aroma dan bentuk makanan pun tidak berubah. Hal ini selalu disampaikan oleh peneliti dan enumerator di awal penelitian sehingga ketika ditemukan hal serupa maka orang tua sudah tidak kesulitan dalam mensiasati pemberian taburia (sprinkle). Hasil ini memperkuat pernyataan bahwa banyak keunggulan yang dimiliki taburia (sprinkle) diantaranya tidak akan mengubah kebiasaan makan balita sehari-hari, tidak mengubah rasa, aroma, atau bentuk (tekstur) makanan balita dan praktis (9).

Melihat efektivitas taburia (sprinkle) dalam memperpendek lama diare dan memperkecil frekuensi diare, taburia (sprinkle) perlu dipertimbangkan untuk ditambahkan dalam terapi baku pada anak diare akut. Pertimbangan lainnya adalah penerimaan masyarakat terhadap taburia (sprinkle) yang positif serta tidak adanya efek samping yang dilaporkan oleh orang tua subjek selama mengonsumsi taburia (sprinkle). Selain itu, pembiayaan tidak akan membebani pasien mengingat harga setiap sachet hanya berkisar Rp 300-500 sehingga dengan rata-rata 3 sachet hanya menambah pengeluaran sebesar Rp 900-1500.

\section{SIMPULAN DAN SARAN}

Hasil penelitian menemukan bahwa suplementasi taburia (sprinkle) dalam terapi baku pada anak diare akut terbukti efektif dalam memperpendek lama diare dan menurunkan frekuensi diare. Taburia (sprinkle) dapat direkomendasikan dalam terapi baku diare akut pada balita. Perspektif di masa mendatang, perlu diteliti pengaruh taburia (sprinkle) pada anak yang menderita diare kronis maupun persisten.

\section{RUJUKAN}

1. Departemen Kesehatan. Laporan hasil riset kesehatan dasar nasional 2007. Jakarta: Depkes; 2008.

2. Departemen Kesehatan. Buku saku petugas kesehatan, lima langkah tuntaskan diare. Jakarta: Depkes; 2011.

3. Chhagan MK, Paed FC, Broeck JV, Luabeya KKA, Mpontshane N, Tucker KL, Bennish ML. Effect of micronutrient supplementation on diarrhoeal disease among stunted children in rural South Africa. Eur J Clin Nutr 2009;63(7):850-7.

4. Lima AA, Soares AM, Lima NL, Mota RM, Maciel BL, Kvalsund MP, Barrett LJ, Fitzgerald RP, Blaner WS, Guerrant RL. Vitamin A supplementation effects on intestinal barrier function, growth, total parasitic and specific Giardia spp. infections in Brazilian children: a prospective randomized, double-blind, placebo-controlled trial. J Pediatr Gastroenterol Nutr 2010;50(3):309-15.

5. Sharieff W, Bhutta Z, Schauer C, Tomlinson G, Zlotkin $S$. Micronutrients (including zinc) reduce diarrhoea in children: the Pakistan sprinkles diarrhoea study. Canada: University of Toronto; 2006.

6. Sastroasmoro S, Ismael S. Dasar-dasar metode penelitian klinis edisi ke-2. Jakarta: Sagung Seto; 2006.

7. Lemeshow S, Hosmer Jr DW, Klar J, Lwanga SK. Besar sampel dalam penelitian kesehatan. Pramono D. 1997 (Alih bahasa). Yogyakarta: UGM Press; 1997.

8. Wahyuni ES. Pengaruh penambahan multivitamin multimineral pada MP-ASI terhadap kejadian ISPA dan diare anak usia 12-24 bulan penderita gizi kurang di Kabupaten Lampung Utara [Tesis]. Yogyakarta: Universitas Gadjah Mada; 2008.

9. Kemenkes RI. Panduan pemberian taburia (sprinkle) (bagi kader). Jakarta: Kemenkes; 2010.

10. Kartono, Sukarti. Angka kecukupan mineral: kalsium, fospor, magnesium, flour. Prosiding Widya Karya 
Nasional Pangan dan Gizi VIII ed. Soekirman dkk. Jakarta: LIPI; 2004.

11. WHO dan Depkes. Pelayanan kesehatan anak sakit di rumah sakit, rujukan pertama di rumah sakit kabupaten. Jakarta: WHO dan Depkes; 2009.

12. Gibney MJ, Margetts BM, Kearney JM, Arab L. Gizi kesehatan masyarakat. Hartono A. (Alih bahasa). Jakarta: Penerbit Buku Kedokteran EGC; 2009.

13. Fortaine O. Evidence for the safety and efficacy of zinc suplementation in the management of diarhea. Geneva: Department of Child and Adolescent Health and Development, WHO \& UNICEF; 2008.

14. Almatsier S. Prinsip dasar ilmu gizi. Jakarta: PT. Gramedia Pustaka; 2004.

15. World Health Organization. Implementing the new recommendations on the clinical management of diarrhea: guidelines for policy makers and programme managers. Geneva: WHO; 2006.

16. Juffrie M. Zinc and probiotic for diarrhea. Suplemen Medika [series online] 2008 [cited 18 Okt 2011];11(XXXIV). Available from: URL: http://www.scribd.com/doc/.../ POUZN-Zinc-Dr-Juffrie-Phd-Medika-Nov08

17. Weber M, Habil. Penerapan oralit dan zinc sebagai protokol terbaru penatalaksanaan diare pada anak. Medika 2011;XXXVII(5).

18. Muhilal, Sulaeman. Angka kecukupan vitamin larut lemak. Prosiding Widya Karya Nasional Pangan dan Gizi VIII, ed. Soekirman dkk. Jakarta: LIPI; 2004.
19. Dewan V, Patwari AK, Jain M, Dewan N. A randomized controlled trial of vitamin A supplementation in acute diarrhea. Indian Pediatr 1995;32(1):21-5.

20. Villamor E, Fawzi WW. Effects of vitamin A supplementation on immune responses and correlation with clinical outcomes. Clin Microbiol Rev 2005;18(3):446-64.

21. Marpaung M. Uji klinis manfaat vitamin A dalam pengobatan diare akut anak [Tesis]. Medan: Universitas Sumatera Utara; 2008.

22. Natsir M. Efek protektif vitamin A terhadap kejadian diare di Kota Palu [Tesis]. Yogyakarta: Universitas Gadjah Mada; 2008.

23. Wahyuni ES, Hadi H, Julia M. Pengaruh penambahan multivitamin multimineral pada MP-ASI terhadap kejadian ISPA dan diare anak usia 12-24 bulan penderita gizi kurang di Kabupaten Lampung Utara [Tesis]. Yogyakarta: Universitas Gadjah Mada; 2008.

24. Mursalim, Juffrie M, Mulyani NS. Pemberian fortifikasi multi-mikronutrien berpengaruh terhadap pertumbuhan balita keluarga miskin. Jurnal Gizi Klinik Indonesia 2011;8(2):69-80.

25. Sampaio DL, de Mattos AP, Ribeiro TC, Leite ME, Cole $\mathrm{CR}$, Costa-Ribeiro H Jr. Zinc and other micronutrients supplementation through the use of sprinkles: impact on the occurrence of diarrhea and respiratory infections in institutionalized children. J Pediatria (Rio J) 2013;89(3):286-93. 